\title{
Nutrients Recovered from Organic Residues as Fertilizers: Challenges to Management and Research Methods
}

\author{
Bente Foereid* \\ Department of Bioeconomy Research, Norway
}

*Corresponding author: Bente Foereid, Department of Bioeconomy Research, Norway.

Received Date: February 19, 2019

Published Date: March 01, 2019

\begin{abstract}
Biofertilizers, fertilizers made from organic residues, could replace some mineral fertilizers, reducing energy consumption and resource mining. The main treatment options are composting, anaerobic digestion, drying, pyrolysis and combustion, they can be used alone or in combination. The quality of biofertilizers depend both on the original residue and on the treatment, but in most cases not all the nutrients are immediately available to plants. It is difficult to predict how available the nutrients are, and when they will become available. The methods to assess and predict nutrient availability are reviewed. Furthermore, the effect of biofertilizers on the environment in the form of nutrient losses and greenhouse gas emissions are reviewed and compared to mineral fertilizers. There is a need to produce biofertilizers with better and more predictable qualities, and also to understand their effects over multiple seasons.
\end{abstract}

Keywords: Organic Residues; Fertilizers; Plant availability; Environmental effects

\section{Introduction}

\section{Organic waste as fertilizers}

Many organic waste streams have high nutrient content. Recent years have seen increasing restriction on release of such waste to the environment, due to risk of eutrophication and other environmental problems [1-4]. However, current management usually only considers this aspect, and not the recycling of nutrients as resources to replace mineral fertilizers. Production of mineral fertilizers is energy intensive, particularly fixation of nitrogen $[5,6]$ and mine mineral resources in a way that is not sustainable in the long run. Particularly phosphorus that is estimated to run out in the next few centuries $[7,8]$. Potassium is also only mined in Europe and Canada, making it difficult for developing countries to get it at affordable prices [9]. It is therefore necessary to develop better systems to recycle nutrients in organic waste streams beck to agriculture to replace mineral fertilizers. There are a number of obstacles to this and needs for both research and societal changes $[10,11]$.
Fertilizers based on organic residues are known under many names, e.g. organic fertilizers, biofertilizers. The term "organic fertilizers can be misinterpreted to mean "fertilizers for organic agriculture", and although organic agriculture may be the most important user (see below) the goal has to be that fertilizers based on organic rest products should be used also outside organic agriculture. Further, current regulations prohibit the use of certain organic rest products (e.g. sewage) in organic agriculture. The term "organic" also excludes ash and precipitates, so "organically based" will be a better term, but maybe too long. However, in this paper I will use the term biofertilizer. It is meant to cover all fertilizers and products used as fertilizers and soil improver of organic origin.

\section{Types of Biofertilizers}

Biofertilizers can be categorized based on substrate/origin or treatment method or both. The main sources of biofertilizers are residues from agriculture, forestry, fishery/aquaculture and food processing, sewage and municipal waste. Treatment options 
include anaerobic digestion for biogas production, composting, combustion and pyrolysis. Drying may be an option to reduce weight if heat is available (e.g. waste heat from power plants or sun). For liquid waste streams (e.g. sewage, digestate after biogas production) there are also specific options, usually mainly aimed at cleaning the water sufficiently to be released to the recipient. Solids are usually separated out by settling, in some cases also mechanical dewatering. To get soluble phosphorus in the solid phase, precipitation chemicals (usually iron or aluminum) are used. Unfortunately, efficient precipitation also means low solubility and availability for plants [12-14]. Nitrogen in the liquid is usually removed by nitrification and subsequent denitrification $[15,16]$. The process is controlled to minimize losses as nitrous oxide (a powerful greenhouse gas), but the reactive nitrogen is lost as nitrogen gas. Better ways to recycle nutrients in liquid waste streams are sought, but they would have to concentrate the nutrients to reduce the energy cost involved in transporting large volumes of liquid.

\section{Bioavailability of nutrients in organic fertilizers}

Plant roots take up nutrients dissolved in water [17]. Nutrients therefore have to be soluble to be taken up by plants. Plants may have some strategies to dissolve nutrients in the root zone, e.g. by exuding acids [18] or induce nutrient mineralisation in the root zone $[19,20]$. Symbiotic fungi (mychorizza) may also said the plant uptake, at least in natural environments where nutrient availability is low [21,22]. However, some salts are so insoluble (e.g. aluminium phosphate that is found in treated sewage sludge) that very little is taken up by plants $[12,14,23]$. Nutrients in organic matter is not available to plants, but most of it will become available over time by decomposition and mineralisation [24-27].

Biofertilizers usually consist of organic residues treated in some way. Some of these treatments may include a decomposition and mineralisation step (anaerobic digestion and composting). These treatments will usually make the nutrients more or faster available to plants. There is some controversy about how combustion and pyrolysis processes affect nutrient availability in the ash or char, but most reports suggest that nutrients become less available [28]. During open treatment processes, nitrogen is lost, mainly as gas, mostly ammonia, but some nitrous oxide is also produced [28-32]. Lower losses can be achieved using feedstock with high carbon to nitrogen ratio, but then the process will go slower, and the required temperatures will usually not be achieved. However, composting oxidizes some ammonia to nitrate [33], which is better for most crop plants. During complete combustion, almost all the nitrogen is lost, as well as sulphur. In pyrolysis, a large fraction of the nitrogen is lost. These options are therefore usually not recommended for feedstock rich in nitrogen unless sterilization is required. During anaerobic digestion, most of the nitrogen is retained, because it is a closed process. Biogas digestate has therefore been found to be the biofertilizer that can best meet plant demand for nitrogen [34-37]. However, as the digestate is rich in ammonium and has relatively high $\mathrm{pH}$, large losses of ammonia can occur during spreading and handling [38].
As some of the nutrients are bound in organic matter in biofertilizers, these nutrients will usually become available slowly over time, and they can act as environmentally friendly slow release fertilizers [39]. This may be an advantage for some crops (e.g. root crops) that take up a large fraction of their nutrients late in the season, but not for grain [40-42]. Biofertilizers usually also contain organic matter, that can increase soil carbon content [43]. This may increase soil fertility and nutrient retention in the longer term. It can also sequester carbon in the soil, and so reduce global warming [44-46]. However, nutrients are mineralised from organic matter slowly. It can therefore be difficult to meet the needs of crops that need to take up large amounts of nutrients early in the season (e.g. grains) with only biofertilizers. As mentioned, biogas digestate is the best candidate, as they contain a large fraction of mineralised nutrients, including nitrogen.

\section{Methods to assess fertilizer value of biofertilizers}

The bioavailability of nutrients in biofertilizers is usually compared to that in mineral fertilizers [47]. The availability in mineral fertilizer is usually assumed to be $100 \%$. Mineral fertilizer equivalent can be calculated as:

$$
\operatorname{MFE}(\%)=\left(\mathrm{X}_{1}-\mathrm{X}_{0}\right) /\left(\mathrm{X}_{\text {full }}-\mathrm{X}_{0}\right) * 100
$$

Where $X_{1}$ is the yield or nutrient uptake with the biofertilizer, $\mathrm{X}=$ is unfertilized yield or uptake and $\mathrm{X}$ full is the yield or uptake with the same total amount of the nutrient applied as mineral fertilizer. However, fertilizer use efficiency can also be calculated based on the total amount of the nutrient applied (X applied):

$$
\text { NUE }(\%)=\left(X_{1}-X_{0}\right) / X_{\text {applied }} * 100
$$

Note that in both case an unfertilized treatment is required as control. The total amount of the nutrient in question in the biofertilizer must be measured, and the amount applied should be optimal and equal to the total amount added with the mineral fertilizer control. When availability is assessed, only one nutrient can be assessed at the time, and all other nutrients should be added in adequate amounts. Pot trials with initially nutrient poor soils done like this are the gold standard of nutrient availability assessment. Often grains are used as test crops [23,48-50]. However, for biofertilizers, there is also a time aspect, as some of the nutrients only become available over time. This can be measured to some extent with grasses as test crops with multiple harvests $[51,52]$. However, this will still only measure one season. Freezing thawing cycles or drying and re-wetting could affect mineralisation and availability this aspect deserves further study. Field test can assess nitrogen bioavailability $[34,36,41,53]$, but it is often difficult to get clear deficiencies of other nutrients than nitrogen. Field experiments are therefore usually not so suitable to assess nutrient availability of materials, but field trials will be needed eventually before biofertilizers are marketed, to confirm what has been found in other tests. Field experiments will be particularly valuable if they can be run for multiple years.

Pot and field experiments are expensive and time consuming to carry out. The large number of potential biofertilizer that also 
have a composition that can vary with production date means that there is a need for faster and cheaper tests that can give at least some idea of nutrient availability in the material. However, this has turned out rather difficult. Whilst the total amount of any element can easily be measured chemically, there are no chemical tests that can tell the exact fraction that is bioavailable. There are, however, some tests that correlate to bioavailability, but usually only under certain conditions and only to some extent.

Mineral nitrogen occurs in two forms in soils, ammonium and nitrate [54]. Both can be taken up by plants, but nitrate is more soluble and can therefore be taken up faster and in larger amounts [55]. Only ammonium as nitrogen source can also be somewhat toxic. In agricultural soils ammonium is usually quickly nitrified to nitrate, but this process acidifies the soil. Ammonium and nitrate can easily be extracted and analysed in standard tests. Some soluble organic nitrogen compounds can also occur in soils and in some biofertilizers, and they will not be picked up by the tests. These may be taken up by plants, it is disputed how important this is [56]. In addition, many biofertilizers continue to mineralize and release soluble nitrogen compounds after addition to the soil. There are no chemical tests to predict how quick this release will be. However, incubations experiments can be way to assess it.

Phosphorous in biofertilizers come in many forms, which can be more or less available to plants [57]. Solubility also depends on soil factors, particularly $\mathrm{pH}$ [58]. Organic phosphorus can be mineralised over time and become bioavailable similarly as nitrogen [59]. Mineral phosphorus can be more or less soluble, and sequential extraction methods correlate to some extent with plant availability $[52,60]$. Recently, passive samples have been developed that can assess the rate of phosphorus release over time [61-63,50]. However, neither of these tests correlate well with bioavailability under all conditions.

Potassium is almost completely soluble, and chemical measurements are therefore usually adequate. Deficiency of other elements needed for plant growth are also rare, although sulphur deficiency can occur, and may not always be picked up because symptoms are similar to nitrogen deficiency [64].

In conclusion, there is a need for better ways to predict plant availability of at least nitrogen and phosphorus. Plant growth trials are the gold standard, but there is a need for quick tests that correlate well with the results of growth trials, or rules for which tests to use under which conditions. Furthermore, there is a need to look beyond the first season or growth cycle.

\section{Treatment options to increase the fraction of nutrients that are recycled}

Most biofertilizers are produced from organic residues treated in some way. Ideally treatment should produce a stable, odor free product, where weight and water content is low, but nutrient are kept concentrated and, on a plant, available form. In addition, the product should be safe, free from pathogens and heavy metal and micro-pollutant concentrations within safe limits. Naturally most treatment options do not meet all these criteria, and it is also possible to combine treatment options. The main treatment options for organic residues are composting, anaerobic digestion, drying, pyrolysis and combustion. The effect of each method is briefly summarized in Table 1.

Composting is often put forward as the best and most environmentally friendly way of treating organic rest products $[65,66]$. However, losses of nitrogen as ammonia can be large, and some losses of greenhouse gases will occur. Most losses happen in the early, thermophilic phase of composting [67]. High temperature is necessary to get a sanitised product. Losses can be reduced by composting in closed containers, reactors etc., however, then aeration has to be ensured. The result of successful composting is a smell free, stable product.

Vermicomposting is composting with earthworm. Often the worms are only added after the thermophilic phase, but there are also options to use earthworms during the entire composting process if lower temperature can be maintained and high temperature is not required to kill pathogens etc. There are reports that vermicomposting makes nutrients plant available to a larger extent than regular composting. During vermicomposting, organic material is "treated" in the gut of earthworms in addition to the microbial breakdown. This will generally make nutrients more plant available than just standard composting [68]. Nitrogen mineralization is quite intense in the gut of earthworms and continues for several hours in fresh earthworm casts [69]. Gosh et al. [70] measured the effect of earthworms on phosporous (P) forms and found that the content of easily extractable P more than doubled in many cases. Other authors have also found vermicompost to improve availability of other nutrients [71-73].

Anaerobic digestion has the advantage of producing biogas for energy in addition an organic rest. The organic rest called digestate [74], is also good biofertilizer. Because anaerobic digestion happens in a closed container, nutrient losses during the process are small. However, because digestate is rich in ammonium and usually has relatively high $\mathrm{pH}$, losses of ammonia during handling and spreading can be a problem. Digestate also has high water content, making transport to areas of need costly in economic and environmental terms [75]. It is possible to reduce water content by dewatering (press or centrifugation), but the most plant available nutrients are in in liquid phase. The solid phase contains nutrients and organic matter and can be used as soil amendments. Sometimes composting can be necessary to stabilize the product and reduce odours. However, we have some evidence that at least if the digestion process has not gone to completion, methane can be emitted during composting (Bergersen, unpublished). There are number of options to recover nutrients from digestate [76].

Drying is the simplest way to reduce water content and make a stable, product that is cheap to transport. It requires energy, but in some cases, this can be available at no or low cost, for example waste heat from electricity generation or sun-drying. 
Ammonia will volatilize during drying, and some filters or stripping can be used to trap the nitrogen. It is usually believed that drying does little to change the plant availability of the nutrients, but there is little research on this [77].

Pyrolyis produces charcoal, "biochar" in addition to some other products and energy. Biochar has been promoted as good soil amendment that can increase nutrient retention in soil among other, and there has been an explosion in biochar research in recent years [78,79]. However, most nitrogen and sulphur is lost during pyrolysis (somewhat depending on conditions) and most of the evidence suggest that phosphorus is left less plant available. Pyrolysis may therefore be good option for organic residues with low nutrient content. It could also be recommended when there is concern for pathogens in the residues. Recently, biochar has been suggested as an amendment in composting or other processes, and it appears that it can reduce nitrogen losses $[80,81]$.

Combustion produces heat energy and ash as a rest product. All nitrogen and sulphur is lost during combustion. Other elements are left in the ashes, most evidence suggests that at least phosphorus is left less plant available than in the original material. Combustion also kills all pathogens etc., and also micro-pollutants are degraded in complete combustion.

There are also a number of options to concentrate nutrients in solution, or to take out products with high nutrient content from liquid waste streams (Table 1).

Table 1: Options for treatment of organic rest products.

\begin{tabular}{|c|c|c|c|c|c|}
\hline & Combustion & Pyrolysis & Drying & Anaerobic digestion & Composting \\
\hline Sanitation & Yes, during the process & Yes, during the process & $\begin{array}{l}\text { Maybe, depending on } \\
\text { temperature }\end{array}$ & $\begin{array}{c}\text { No, must be done } \\
\text { separately (before) }\end{array}$ & $\begin{array}{l}\text { Yes, if the temperature } \\
\text { is high enough }\end{array}$ \\
\hline Energy production & Yes & Yes & No, requires energy & Yes & $\begin{array}{c}\text { No, but some } \\
\text { technologies can } \\
\text { make use of the heat } \\
\text { produced }\end{array}$ \\
\hline Stable rest product & Yes & Yes & $\begin{array}{l}\text { Yes, at least until re- } \\
\text { wetted }\end{array}$ & Not always & $\begin{array}{l}\text { Yes, when the process } \\
\text { optimal and complete }\end{array}$ \\
\hline Loss of nutrients & Yes, all nitrogen & $\begin{array}{l}\text { Yes, but losses less } \\
\text { than complete } \\
\text { combustion }\end{array}$ & $\begin{array}{c}\text { Yes, ammonia loss, } \\
\text { can be captured in } \\
\text { biofilters }\end{array}$ & $\begin{array}{l}\text { No, little during the } \\
\text { process, but losses } \\
\text { during application can } \\
\text { be large }\end{array}$ & $\begin{array}{l}\text { Yes, ammonia loss, } \\
\text { but amount of loss } \\
\text { depends on method }\end{array}$ \\
\hline Suitable substrates & $\begin{array}{l}\text { Dry, low nutrient } \\
\text { content }\end{array}$ & Same as combustion? & $\begin{array}{l}\text { Relatively low water } \\
\text { and nutrient content }\end{array}$ & $\begin{array}{l}\text { High water and } \\
\text { nutrient content }\end{array}$ & $\begin{array}{c}\text { Wet, nutrient rich and } \\
\text { with some structural } \\
\text { material }\end{array}$ \\
\hline $\begin{array}{l}\text { Water content and } \\
\text { weight of rest product }\end{array}$ & $\begin{array}{c}\text { No water, concentrated } \\
\text { nutrients }\end{array}$ & $\begin{array}{l}\text { No water, somewhat } \\
\text { concentrated nutrients }\end{array}$ & $\begin{array}{l}\text { Little water, weight } \\
\text { reduced }\end{array}$ & $\begin{array}{l}\text { High water and } \\
\text { nutrients content. } \\
\text { Dewatering reduces } \\
\text { water content, but } \\
\text { also the content of } \\
\text { bioavailable nutrients }\end{array}$ & $\begin{array}{l}\text { Relatively low water } \\
\text { content, nutrients } \\
\text { depends on feedstock } \\
\text { and process. }\end{array}$ \\
\hline
\end{tabular}

\section{Biofertilizers in the environment}

For all fertilizers, the goal is that they should be taken up by plants when the plant needs them, and as little as possible should be lost to the environment. Losses to the environment can be both as leaching and runoff and for nitrogen also gaseous losses. Losses is more or less the inverse of plant availability, nutrients that are not taken up by plants will be lost to the environment in some way. Good and predictable plant availability is therefore good both for agronomic performance and for the environment. How beneficial it is to use biofertilizers therefore depend on crop type, but in overall, most of the evidence suggests that nutrient losses are higher when biofertilizers are used, than when mineral fertilizers are used. This is of course no argument against biofertilizers, because they are recycled nutrients. However, there is a need both for better treatment options for organic residues to produce tailor made fertilizers, and better guidelines for how to use biofertilizers, both alone, and in combination with mineral fertilizer.

Use of biofertilizers will in general decrease global warming potential of agriculture, because production of nitrogen fertilizers is energy intensive, and nitrogen in biofertilizers can reduce the need for mineral fertilizers. However, greenhouse gases are also produced in agricultural soil, nitrous oxide is the most important [82-84]. Addition of nitrogen fertilizers stimulates production of nitrous oxide in soil. Nitrous oxide production after addition of biofertilizers has not been so much studied, but there are indications that it could be somewhat higher per unit added nitrogen than mineral fertilizers. The main reason for this is that organic matter is then added with the nitrogen, which also stimulates emissions. This is no reason not to use biofertilizers, but specific practises should be developed to minimize emissions as much as possible.

Organic agriculture is often put forward as the solution to the problems of modern intensive agriculture. However, the evidence is inconclusive. Often as high or higher leaching losses are found in organic as in conventional agriculture, and at least if it is taken into account that yields are lower in organic agriculture, so that higher areas are required, the total environmental impact of organic agriculture is often higher [85]. However, organic agriculture does provide an incentive to use the organic residues that are available, even if mineral fertilizer is cheaper and easier to use. Rules for organic agriculture differ somewhat in different countries and 
regions, but sewage is usually not allowed, and some other waste products. Also, those residues that are allowed e.g. food waste are often treated with some suspicion. However, if organic agriculture is going to continue to expand, and sell products out of the farm, recycling of nutrients back from society in one form or another seems inevitable. Both rules and attitudes may need to be relaxed. Then organic agriculture will be the best marked for biofertilizers.

\section{Conclusion}

In this review, we have seen that biofertilizers can partly replace mineral fertilizers and thereby reduce resource mining and energy use for production of mineral fertilizers. However, when applied to soil, biofertilizers have the same problems as mineral fertilizers and some more. One of the main drawback is that not all nutrients in biofertilizers are immediately available, and it is difficult to predict when and if they will become available. That means that plant utilization is lower and losses to the environment are often larger when biofertilizers are used. However, more research on how to use biofertilizers optimally, possibly also in combination with mineral fertilizers, as well as better standardization of biofertilizer products may reduce some of these problems. Furthermore, until now, bioavailability of nutrients has only been evaluated in finalized products. Treatment options for organic residues should rather be developed to maximize the utilization of nutrients. In this way a circular economy can be developed.

\section{Acknowledgement}

The work on this review was funded by the Norwegian Research Council grant: SIS - Sustainable recycling of organic waste resources in the future bio economy.

\section{Conflicts of Interest}

Author declare that there is no conflicts of interest.

\section{References}

1. Tilman D, Cassman KG, Matson PA, Naylor R, Polasky S, et al. (2002) Agricultural sustainability and intensive production practices. Nature 418(6898): 671-677.

2. Camargo JA, Alonso A (2006) Ecological and toxicological effects of inorganic nitrogen pollution in aquatic ecosystems: A global assessment Environment International 32(6): 831-849.

3. Guo JH, Liu XJ, Zhang Y, Shen JL, Han WX, et al. (2010) Significant acidification in major Chinese croplands. Science 327(5968): 10081010 .

4. Vogt RD (2012) Water quality in a changing environment. Public Service Review: European Union.

5. Woods J, Williams A, Hughes JK, Black M, Murphy R (2010) Energy and the food system. Philos Trans R Soc Lond B Biol Sci 365(1554): 29913006.

6. Gellings CW, Parmenter KE (2016) Energy Efficiency in Fertilizer Production and Use. In: Efficient Use and Conservation of Energy (ed), EOLSS Publishing Co Ltd Oxford, USA.

7. Cordell D, Drangert JO, White S (2009) The story of phosphorus: Global food security and food for thought. Global Environmental Change 19(2): 292-305.

8. Van Kauwenbergh SJ (2010) World phosphate rock reserves and resources. Muscle Shoals, Alabama, USA, International Fertilizer Development Center, pp. 48.

9. Manning DAC (2010) Mineral sources of potassium for plant nutrition. Agronomy, Sustainability and Development 2: 188-201.
10. Hoornweg D, Bhada Tata P, Kennedy C (2013) Environment: waste production must peak this century. Nature 502: 615-617.

11. Buckwell A, Nadeu E (2016) Nutrient Recovery and Reuse (NRR) in European Agriculture. A Review of the Issues, Opportunities, and Actions. RISE Foundation, Brussels.

12. Maguire RO, Sims JT, Dentel SK, Coale FJ, Mah JT (2001) Relationships between biosolids treatment process and soil phosphorus availability. Journal of Environmental Quality 30: 1023-1033.

13. Bøen A, Haraldsen TK (2013) Meat and bone meal and biosolids as slowrelease phosphorus fertilizers. Agriculture and Food Science 22(2): 235246.

14. Ogaard AF, Brod E (2016) Efficient phosphorus cycling in food production: predicting the phosphorus fertilization effect of sludge from chemical wastewater treatment. Agricultural and Food Chemistry 64(24): 4821-4829.

15. Gray NF (1999) Water Technology: An introduction for Scientists and Engineers.

16. Massara TM, Malamis S, Guisasola A, Baeza JA, Noutsopoulos C, et al (2017) A review on nitrous oxide $\left(\mathrm{N}_{2} \mathrm{O}\right)$ emissions during biological nutrient removal from municipal wastewater and sludge reject water Science of the Total Environment 596-597: 106-123.

17. Salisbury FB, Ross CW (1992) Plant physiology. Wadsworth Publ Co, Belmont, CA.

18. Hinsinger P (2001) Bioavailability of soil inorganic P in the rhizosphere as affected by root induced chemical changes: a review. Plant and Soil 237(2): 173-195.

19. Robinson D, Griffiths B, Ritz K, Wheatley R (1989) Root-induced nitrogen mineralisation: A theoretical analysis. Plant and Soil 117(2): 185-193.

20. Liljeroth E, Baath E, Mathasson I, Lundborg T (1990) Root exudation and rhizoplane bacterial abundance of barley (Hordeum vulgare L) in relation to nitrogen fertilisation and root growth. Plant and Soil 127: 8189.

21. Cavagnaro TR, Bender SF, Asghari HR, van der Heijden MGA (2015) The role of arbuscular mycorrhizas in reducing soil nutrient loss. Cell press 20(5): 283-290.

22. Van Der Heijden MGA, De Bruin S, Luckerhoff L, Van Logtestijn RSP, Schlaeppi K (2016) A widespread plant-fungal-bacterial symbiosis promotes plant biodiversity, plant nutrition and seedling recruitment. ISME J 10(2): 389-399.

23. Bøen A, Haraldsen TK, Krogstad T (2013) Large differences in soil phosphorus solubility after the application of compost and biosolids at high rates. Acta Agriculture Scandinavica 63: 473-482.

24. Christensen BT, Johnston AE (1997) Soil organic matter and soil quality - lessons learned from long-term experiments at Askov and Rothamsted. Developments in Soil Science 25: 399-430.

25. Reeves DW (1997) The role of soil organic matter in maintaining soil quality in continuous cropping systems. Soil and Tillage Research 43(12): 131-167.

26. Lal R, Griffin M, Apt J, Lave LM, Morgan G (2004) Managing Soil Carbon. Science 304(5669): 393.

27. Lal R (2009) Challenges and opportunities in soil organic matter research. European Journal of Soil Science 60(2): 158-169.

28. Wang J, Hu Z, Xu X, Jiang X, Zheng B, et al. (2014) Emissions of ammonia and greenhouse gases during combined pre-composting and vermicomposting of duck manure. Waste Management 34(8): 15461552.

29. Hao X, Chang C, Larney FJ (2004) Carbon, nitrogen balances and greenhouse gas emission during cattle feedlot manure composting. J Environ Qual 33(1): 37-44.

30. Amlinger F, Peyr S, Cuhls C (2008) Greenhouse gas emissions from composting and mechanical biological treatment. Waste Manag Res 26(1): 47-60.

31. Boldrin A, Andersen JK, Møller J, Christensen FE (2009) Compost and compost utilization: accounting of greenhouse gases and global warming contributions. Waste Management \& Research 27(8): 800-812.

32. Ermolaev E, Jarvis Å, Sundberg C, Smårs S, Pell M, et al. (2015) Nitrous oxide and methane emissions from food waste composting at different temperatures. Waste Management, 46:113-119. 
33. Cáceres R, Malińska K, Marfà $O$ (2018) Nitrification within composting: A review. Waste Management 72: 119-137.

34. Abubaker J, Risberg K, Pell M (2012) Biogas residues as fertilisers Effects on wheat growth and soil microbial activities. Applied Energy 99: $126-134$

35. Möller K, Müller T (2012) Effects of anaerobic digestion on digestate nutrient availability and crop growth: A review. Engineering in Life Science 12: 242-257

36. Kristoffersen AØ, Skretting J, Bergjord AK, Haraldsen TK (2013) Gjødselvirkning av organisk avfall fra storsamfunnet. Bioforsk Fokus 8 : 149-156.

37. Odlare M, Pell M, Svensson K (2008) Changes in soil chemical and microbiological properties during 4 years of application of various organic residues. Waste Management 28: 1246-1253.

38. Amon B, Kryvoruchko V, Amon T, Zechmeister Boltenstern S (2006) Methane, nitrous oxide and ammonia emissions during storage and after application of dairy cattle slurry and influence of slurry treatment. Agriculture, Ecosystems \& Environment 112(2-3): 153-162.

39. Chen J, Lü S, Zhang Z, Zhao X, Li X, et al. (2018) Environmentally friendly fertilizers: A review of materials used and their effects on the environment. Sci Total Environ 613-614: 829-839.

40. Amlinger F, Götz B, Dreher P, Geszti J, Weissteiner C (2003) Nitrogen in biowaste and yard waste compost: dynamics of mobilisation and availability- a review. European Journal of Soil Biology 39(3): 107-116.

41. Erhart E, Hartl W, Putz B (2005) Biowaste compost affects yield, nitrogen supply during the vegetation period and crop quality of agricultural crops. European Journal of Agronomy 23(3): 305-314.

42. Rothamsted Research (2008) Guide to the Classical and other Longterm Experiments, Datasets and Sample Archive, Rothamsted Research, Harpenden, Herts, UK.

43. Lutzov Mv, Kogel Knabner I, Ekscmitt K, Matzner E, Guggenberger G, et al. (2006) Stabilization of organic matter in temperate soils: mechanisms and their relevance under different conditions - a review. European Journal of Soil Science 57: 426-445.

44. IPCC (2014) Climate Change 2014: Synthesis Report. Contribution of Working Groups I, II and III to the Fifth Assessment Report of the Intergovernmental Panel on Climate Change. IPCC, Geneva, Switzerland.

45. Lal R (2004) Soil carbon sequestration impacts on global climate change and food security. Science 304(5677): 1623-1627.

46. Lehmann J, Kleber M (2015) The contentious nature of soil organic matter. Nature 528: 60-68.

47. Delin S, Stenberg B, Nyberg A, Brohede L (2012) Potential methods for estimating nitrogen fertilizer value of organic residues. Soil Use and Management 28(3): 283-291.

48. Haraldsen TK, Andersen U, Krogstad T, Sørheim R, (2011) Liquid digestate from anaerobic treatment of source-separated household waste as fertilizer to barley. Waste Manag Res 29(12): 1271-1276.

49. Brod E, Haraldsen T, Breland T (2012) Fertilization effects of organic waste resources and bottom wood ash: results from a pot experiment Agricultural and Food Science 21(4): 332-347.

50. Foereid B (2017) Phosphorus availability in residues as fertilizers in organic agriculture. Agricultural and Food Science 26(1): 25-33.

51. Brod E, Øgaard AF, Hansen E, Wragg D, Haraldsen TK, et al. (2015) Waste products as alternative phosphorus fertilisers part I: inorganic P species affect fertilisation effects depending on soil pH. Nutrient Cycling in Agroecosystems 103: 167-185.

52. Brod E, Øgaard AF, Haraldsen TK, Krogstad T (2015) Waste product as alternative phosphorus fertilisers part II: Predicting P fertilisation effects by chemical extraction. Nutrient Cycling in Agroecosystems 103: 187-199.

53. Odlare M, Pell M, Arthurson JV, Abubaker J, Nehrenheim E (2014) Combined mineral $\mathrm{N}$ and organic waste fertilization - effect on crop growth and soil properties. Journal of Agricultural Science 152: 134-145.

54. Mac Donald JG, Nielsen R (1978) Nitrogen in the Environment: Vol 1 Nitrogen behaviour in field soil. Academic Press.

55. Havlin JL, Tisdale SL, Beaton JD, Nelson WL (2005) Soil Fertility and Fertilizers I: Yarnell D (ed). New Yersey: Pearson Education pp. 137-141.
56. Jones DL, Healey JR, Willett VB, John F. Farrar JF, et al. (2005) Dissolved organic nitrogen uptake by plants-an important $\mathrm{N}$ uptake pathway? Soil Biology \& Biochemistry 37(3): 413-423.

57. Möller K, Oberson A, Else K, Bünemann EK, Cooper J, et al. (2018) Improved Phosphorus Recycling in Organic Farming: Navigating Between Constraints. Advances in Agronomy 147: 159-237.

58. Oburger E, Jones DL, Wenzel WW (2011) Phosphorus saturation and pH differentially regulate the efficiency of organic acid anion-mediated $\mathrm{P}$ solubilization mechanisms in soil. Plant and Soil 341: 363-382.

59. Noack SR, McLaughlin MJ, Smernik RJ, Mc Beath TM, Armstrong RD (2012) Crop residue phosphorus: speciation and potential bioavailability. Plant and Soil 359: 375-385.

60. Toor GS, Hunger S, Peak JD, Sims T, Sparks DL, et al. (2006) Advances in characterisation of Phosphorus in Organic wastes: Environmental and Agronomic Applications. Advances in Agronomy 89: 1-72.

61. Mason SD, Mc Neill A, Mc Laughlin, Zhang H (2010) Prediction of wheat response to an application of phosphorus under field conditions using diffusive gradients in thin-films (DGT) and extraction methods. Plant and Soil 337: 243-258.

62. Tandy S, Mundus S, Yngvessen J, Bang TC, Lombi E, et al. (2011) The use of DGT for prediction of plant available copper, zinc and phosphorus in agricultural soils. Plant and Soil 346(1-2): 167-180.

63. Six L, Smolders E, Merckx R (2013) The performance of DGT versus conventional soil phosphorus tests in tropical soils-maize and rice responses to $\mathrm{P}$ application. Plant and Soil 366(1-2): 49-66.

64. Skwierawska M, Benedycka Z, Jankowski K, Skwierawski A (2016) Sulphur as a fertiliser component determining crop yield and quality. Journal of Elementology 21(2): 609-623.

65. Sharma VK, Canditelli M, Fortuna F, Cornacchia G (1997) Processing of urban and agro-industrial wastes by aerobic composting - a review. Energy Conservation and Management 38: 453-478.

66. Sørheim R, Lystad H, Molland O (1999) Prosesser ved kompostering matavfall-Litteraturoversikt. Jordforsk Rapport 60,18 pp.

67. Diaz LF, Savage GM (2007) Factors that affect the process. Waste Management Series 8: 49-65.

68. Kaushik P, Garg VK (2003) Vermicomposting of mixed textile mill sludge and cow dung with epigeic earthworm Eisenia foetida. Bioresource Technology 90(3): 311-316

69. Mariani L, Jimenez JJ, Asakawa N, Thomas RJ, DecaënsT (2007) What happens to earthworm casts in the soil? A field study of carbon and nitrogen dynamics in Neotropical savannahs. Soil Biology \& Biochemistry 39: 757-767.

70. Gosh M, Chattopadhyay GN, Baral K (1999) Transformation of phosphorous during vermicomposting. Bioresource Technology, 69(2): 149-154.

71. Padmavathiamma PK, Li LY, Kumari UR (2008) An experimental study of vermi-biowaste composting for agricultural soil improvement. Bioresource Technology 99(6): 1672-1681.

72. Solis Mejia L, Islas Espinoza M, Esteller MV (2012) Vermicomposting of sewage sludge: Earthworm population and agronomic advantages. Compost Science and Utilization 20: 11-17.

73. Suthar S, Kumar K, Mutiyar PK (2015) Nutrient recovery from compostable fractions of municipal solid wastes using vermitechnology. Journal of Material Cycles and Waste Management 17(1): 174-184

74. Al Seadi T, Lukehurst C (2012) Quality management of digestate from biogas plants used as fertiliser. IEA Bioenergy Task 37 - Energy from Biogas.

75. Drosg B, Fuchs W, Al Seadi T, Madsen M, Linke B (2015) Nutrient Recovery by Biogas Digestate Processing. IEA Bioenergy.

76. Monfet E, Aubry G, Ramirez AA (2018) Nutrient removal and recovery from digestate: a review of the technology. Biofuels 9: 247-262.

77. Knoop C, Dornack C, Raab T (2018) Effect of drying, composting and subsequent impurity removal by sieving on the properties of digestates from municipal organic waste. Waste Manag 72: 168-177.

78. Spokas KA, Cantrell KB, Novak JM, Archer DW, et al. (2012) Biochar: A Synthesis of its agronomic impact beyond carbon sequestration. Journal of Environmental Quality 41: 973-989 
79. Clough TJ, Condron LM, Kamman C, Muller C (2013) A review of Biochar and Soil Nitrogen Dynamics. Agronomy 3: 275-293.

80. Barthod J, Rumpel C, Dignac MF (2018) Composting with additives to improve organic amendments. A review Agronomy for Sustainable Development 38: 17

81. Mupambwa HA, Nyari P, MnkeniS (2018) Optimizing thevermicomposting of organic wastes amended with inorganic materials for production of nutrient-rich organic fertilizers: a review. Environmental Science and Pollution Research 25: 10577-10595.

82. Bouwman AF, Boumans LJM, Batjes NH (2002) Emissions of $\mathrm{N}_{2} \mathrm{O}$ and $\mathrm{NO}$ from fertilized fields; Summary of available measurement data. Global Biogeochemical Cycles 16(4): 6-1-6-13.
83. Butterbach Bahl K, Baggs EM, Dannenmann M, Kiese R, Zechmeister Boltenstern S (2013) Nitrous oxide emissions from soils: how well do we understand the processes and their controls? Philosophical Transactions of the Royal Society. B 368.

84. Oertel C, Matschullat J, Zurbaa K, Zimmermanna F, Erasmib S (2016) Greenhouse gas emissions from soils-A review. Chemie der Erde 76 : 327-352.

85. Six L, Smolders E, Merckx R (2014) Testing phosphorus availability for maize with DGT in weathered soils amended with organic materials. Plant and Soil 376(1-2): 177-192. 